\title{
Varietal Hybrid Performance of Bitter Gourd under Poly House Condition
}

\author{
K.P. Asati ${ }^{*}$, Swati Barche ${ }^{1}$ and Kamal Singh Kirad ${ }^{2}$ \\ ${ }^{1}$ R.V.S.K.V.V, Department of Horticulture, College of Agriculture, Indore \\ (M.P.)-452001, India \\ ${ }^{2}$ R.V.S.K.V.V, KVK, Dhar (M.P.), India \\ *Corresponding author
}

\section{A B S T R A C T}

K e y w o r d s
Polyhouse,
Bittergourd,
Growth, Yield and
attributing traits
Article Info
Accepted:
$\begin{aligned} & \text { 28 January } 2018 \\ & \text { Available Online: } \\ & \text { 10 February } 2018\end{aligned}$

\section{Introduction}

Bittergourd is one of the most important monoecious curcubit grown throughout India owing to its nutritive value and therapeutic properties especially ascorbic acid and iron (Behera, 2014). It is extensively grown for fresh market and China leads in production followed by India. It is grown throughout the year in southern states of India. In plains of Northern India, it is grown during summer and rainy seasons but least grown in late kharif season. However, it is grown commercially throughout the country. Production of bitter gourd is mainly cultivated in open condition where it faces biotic and abiotic stresses and low yield with poor quality fruits. In polyhouse farming, crop can be protected from adverse environmental condition and achieve higher crop yield with quality. But suitable varieties under polyhouse condition are not evaluated. Hence, considering the importance of varieties under polyhouse condition the experiment has been conducted to test the varietal hybrid performance in relation to growth, yield and quality traits.

\section{Materials and Methods}

An assessment trial was conducted in poly house, Dept. of Horticulture, College of Agriculture, RVSKVV, Indore, M. P. during 
the year 2015-16.The experimental material for the present investigation was comprised of ten varieties grown in Randomized Block Design with three replications. The soil of experiment site was red clay. Raised bed and furrows were made. Two seeds per hill was sown. The plants were trained upwards so that the main stem was allowed to climb to the overhead wire along a rope. Wires were fixed 8-9 feet above the ground. The twine of each plant was alternatively tied to the horizontal overhead wires running along with the length of rows. The base of the string was anchored loosely to the base of the stem with a non-slip noose. As the main stem developed, it was trellised on the twine upto the height of horizontal wires (8-9 feet height) and then the vines were again turned downward directions.

All the observations related to growth $\&$ yield attributing traits of bittergourd were recorded as per standard procedures from five randomly selected plants of each variety in all the replications and their mean were worked out for statistical analysis (Panse and Sukhatme, 1989).

\section{Results and Discussion}

The mean performance of the different varieties of bittergourd in polyhouse condition shown in Table 1 revealed significant result on growth and yield parameters. The variety Jhalri have maximum seed germination percentage (86) while minimum was recorded in sapna (79.66). This variation may be due to the genetic makeup of the cultivars, which responded differently to the environmental conditions. These results are in the accordance with the findings of Hamid et al., (2002).

The maximum vine length $(5.90 \mathrm{~m})$ and number of leaves per plant (213.55) was found in the variety Pallavi while shortest length and minimum no. of leaves were recorded in the variety Swastik. $(5.13 \mathrm{~m}$ and 199.86, respectively). Increase vine length might be due to their inherent genetic makeup and interaction response of microclimate prevails under poly house condition. The similar finding was recorded by Rani (2014). The vine length is directly proportionate and increased vine length may contribute more number of leaves. These findings are in agreement with the findings of Islam et al., (2014).

The significantly minimum intermodal distance and leaf area was found in variety varun $\left(6.4 \mathrm{~cm}\right.$ and $\left.34.85 \mathrm{~cm}^{2}\right)$ while maximum in Jhalri Priya 5 (98.2 and $53.93 \mathrm{~cm}^{2}$, respectively.). Internodal distance trait is a varietal character or may be influenced by the partitioning of photosynthates that influence the growth of vine. These findings are in agreement with the results reported by Rani (2014). Minimum days taken to first flowering and days taken to fruit initiation was recorded in variety jhalri (39.43 and 45.75,respectively) while maximum days taken to flowering was recorded in Sapna (47.3) and maximum days taken to fruit initiation was in Varun (57.98).

The variety Jhalri Priya 5 recorded the highest fruit length $(27.87 \mathrm{~cm})$ and diameter $(12.73 \mathrm{~cm})$ while minimum highest fruit length was noted in variety Chu-Chu $(18.42 \mathrm{~cm})$ and Pallavi $(11.33 \mathrm{~cm})$.The variation might be due to the vigor of the crop and environmental factors. These findings are in the conformity with the work done by Nugullie and Biswas (2015).

Table 2 clearly indicated the Jhalri Priya 5 produced maximum fruit weight (202.44g) while lowest in Sapna (144.16g). The variation might be due to the variation in the size of the fruit and their adaption in polyhouse condition. The variety Pallavi was found significantly highest number of fruits per plant and lowest was recorded in Jhalri Priya5. The variation might be due to having more pistillate flowers and will set more fruits. 
Table.1 Varietal hybrid performance of bitter gourd under poly house condition

\begin{tabular}{|l|l|l|l|l|l|l|l|}
\hline Verity & $\begin{array}{l}\text { Seed } \\
\text { germina } \\
\text { tion }(\boldsymbol{\%})\end{array}$ & $\begin{array}{l}\text { Vine length } \\
\left(\begin{array}{l}\text { (meter) } \\
(\mathbf{1 2 0} \text { DAS) }\end{array}\right.\end{array}$ & $\begin{array}{l}\text { No. of } \\
\text { leaves/plant } \\
(\mathbf{1 2 0} \text { DAS })\end{array}$ & $\begin{array}{l}\text { Inter-nodal } \\
\text { Distance } \\
(\mathbf{c m})\end{array}$ & $\begin{array}{l}\text { Leaf Area } \\
\left(\mathbf{c m}^{2}\right)\end{array}$ & $\begin{array}{l}\text { Days taken } \\
\text { to first } \\
\text { flowering }\end{array}$ & $\begin{array}{l}\text { Days taken to } \\
\text { first fruit } \\
\text { initiation }\end{array}$ \\
\hline NS-454 & 85.0 & 5.43 & 205.60 & 6.55 & 35.42 & 45.73 & 53.53 \\
\hline US-6214 & 85.0 & 5.56 & 210.86 & 7.65 & 42.49 & 43.75 & 48.65 \\
\hline Jhalri & 86.0 & 5.46 & 201.63 & 6.43 & 38.44 & 39.43 & 45.75 \\
\hline Pallavi & 81.66 & 5.90 & 213.55 & 7.42 & 45.29 & 45.53 & 54.63 \\
\hline Veda & 84.33 & 5.50 & 207.96 & 7.42 & 39.76 & 42.65 & 49.77 \\
\hline Varun & 82.0 & 5.60 & 207.86 & 6.40 & 34.85 & 47.73 & 57.98 \\
\hline Sapan & 79.66 & 5.46 & 200.97 & 7.77 & 40.06 & 47.30 & 55.66 \\
\hline Swastik & 83.0 & 5.13 & 199.86 & 6.98 & 48.10 & 45.98 & 54.98 \\
\hline Chu-Chu & 82.66 & 5.80 & 211.63 & 6.40 & 48.13 & 45.53 & 52.87 \\
\hline Jhalri Priya -5 & 83.53 & 5.66 & 208.42 & 8.20 & 53.93 & 41.65 & 48.09 \\
\hline SEm ( \pm ) & 1.39 & 0.14 & 2.14 & 0.15 & 0.99 & 0.25 & 0.29 \\
C.D. at 5\% level & 4.12 & 0.14 & 6.34 & 0.46 & 2.95 & 0.76 & 0.85 \\
\hline
\end{tabular}

Table.2 Varietal hybrid Performance of yield and its attributing traits of bitter gourd Under Polyhouse Condition

\begin{tabular}{|c|c|c|c|c|c|c|}
\hline Verity & $\begin{array}{l}\text { Average fruit } \\
\text { length }(\mathrm{cm})\end{array}$ & $\begin{array}{l}\text { Average fruit } \\
\text { diameter }(\mathrm{cm})\end{array}$ & $\begin{array}{l}\text { Fruit weight } \\
\text { (g) }\end{array}$ & $\begin{array}{l}\text { No. of fruits } \\
\text { per plant }\end{array}$ & $\begin{array}{l}\text { Fruit yield } \\
\text { (q/ha.) }\end{array}$ & C:B ratio \\
\hline NS-454 & 22.54 & 13.06 & 174.09 & 27.08 & 171.60 & $1: 2.63$ \\
\hline US-6214 & 19.21 & 13.66 & 175.76 & 25.32 & 162.90 & $1: 2.44$ \\
\hline Jhalri & 23.65 & 14.20 & 174.74 & 23.88 & 151.60 & $1: 2.21$ \\
\hline Pallavi & 18.86 & 11.33 & 195.06 & 29.08 & 188.30 & $1: 2.98$ \\
\hline Veda & 22.63 & 11.96 & 199.40 & 24.38 & 121.20 & $1: 1.56$ \\
\hline Varun & 21.42 & 13.73 & 176.84 & 26.62 & 139.10 & $1: 1.94$ \\
\hline Sapan & 23.42 & 13.86 & 144.16 & 26.75 & 176.60 & $1: 2.73$ \\
\hline Swastik & 19.65 & 12.96 & 178.52 & 23.44 & 116.20 & $1: 1.46$ \\
\hline Chu-Chu & 18.42 & 11.96 & 156.44 & 24.72 & 139.90 & $1: 1.96$ \\
\hline Jhalri priya -5 & 27.87 & 12.73 & 202.44 & 19.33 & 226.20 & $1: 3.79$ \\
\hline $\operatorname{SEm}( \pm)$ & 0.27 & 0.37 & 3.65 & 1.45 & 0.31 & \\
\hline C.D. at $5 \%$ level & 0.81 & 1.10 & 10.85 & 4.58 & 0.93 & \\
\hline
\end{tabular}

These findings are in the conformity with the work done by Islam et al., (2010). It is clearly indicated that the Jhalri Priya5 produced maximum yield (226.20 q/ha) and minimum was recorded in the variety swastika $116.20 \mathrm{q} / \mathrm{ha}$. The variation in fruit yield might be due to fruit set percentage, fruit length, fruit weight, genetic nature and vigor of the crop. The highest $\mathrm{B}$ : $\mathrm{C}$ ratio was found in Jhalri Priya -5 (1:3.79) while minimum was found in Jhalari. (1:2.21). In summary it is concluded that the significantly highest fruit yield is recorded in the variety Jhalri Priya 5 hybrid under poly house condition in late kharif season and polyhouse grower may take this variety as off season and earn more money.

\section{References}

Behera T.K. 2014. Heterosis in bittergourd. J. New seeds. 6:217-222.

Hamid, A.J., Balach, J.D., and Khan, N. 2002. Performance of six cucumber genotypes in Pakistan Int. J. Agric. \& Biol., 4(4): 491-492. 
Islam, M.R., Hossain, M.S., Bhuiyan, M.S.R and Hassan G.N and Sayed, A 2010. Multivariate analysis of bitter gourd. Middle East J. scientific Res. 5 (2): 8690.

Islam, M.S., Mia, M.A.B., Das, M.R., Hossain, T, Ahmed, J.U and Hossain, M.M. 2014. Pak. J. Agric. Sci.51 (3), 651-658
Nugullie, R. and Biswas, P.K.2015. Evaluation of bitter gourd genotypes for yield attributes in Mokokchung district. Nagaland Int. J. Farm. Sci.5 (3):56-59.

Panse VG and Sukhatme PV 1989. Statistical methods for Agricultural workers. ICAR. New Delhi.

Rani, K.R., 2014. Performance of bittergourd genotypes for yield and earliness. Ann. Of plant and soil Res.16 (4): 330-333.

\section{How to cite this article:}

Asati, K.P., Swati Barche and Kamal Singh Kirad. 2018. Varietal Hybrid Performance of Bitter Gourd under Poly House Condition. Int.J.Curr.Microbiol.App.Sci. 7(02): 3581-3584. doi: https://doi.org/10.20546/ijcmas.2018.702.425 